\title{
Review on Knowledge Towards Food Processing and Use of Technologies
}

\author{
Yimer Mihretie* \\ Depertment of Human Nutrition, Kotebe Metropolitan University, Ethiopia \\ *Corresponding author: Yimer Mihretie, Depertment of Human Nutrition, Kotebe Metropolitan University, Addis Ababa, Ethiopia. \\ To Cite This Article: Yimer Mihretie. Review on Knowledge Towards Food Processing and Use of Technologies. Am J Biomed Sci \& Res. 2019 - 1(2). \\ AJBSR.MS.ID.000516. DOI: 10.34297/AJBSR.2019.01.000516
}

Received: January 13, 2019 | Published: January 23, 2019

\begin{abstract}
Food processing is any deliberate change in a food that occurs before it's available for us to eat. It can be as simple as freezing or drying food to preserve nutrients and freshness, or as complex as formulating a frozen meal with the right balance of nutrients and ingredient. This article aimed at review on Knowledge towards food processing and use of technologies. According to a study done in Bangkok on a sample of 150 processed food consumers, most of the respondents have a general knowledge of processed food, but they have a lower knowledge about the hazards of processed food. Historically, the most important reason to process or prepare foods has been to make them last longer before spoiling. In 1980, the USDA Berglund Report was published providing recommendations on organic farming. However, it wasn't until 1990, with the Organic Foods Production Act (OFPA) that organic farming changed significantly. According to this study, women are more knowledgeable regarding organic foods than men as [10] found that most students agreed that organic food is healthier and disagreed that organic foods are dangerous for their health. In general, majority of the community respondents thought that food processing is healthy and contain high nutritional value product practices are in harmony with nature, environment and animals are getting respect from organic farmers who do not use chemicals and GMOs in farming.
\end{abstract}

Keywords: Genetically modified, Food processing, Animal, Fruits and vegetables

\section{Introduction}

Food processing is any deliberate change in a food that occurs before it's available for us to eat. It can be as simple as freezing or drying food to preserve nutrients and freshness, or as complex as formulating a frozen meal with the right balance of nutrients and ingredient [1].

Food processing began about many years ago when our distant ancestors put flame to food and "discovered" cooking. After that came fermenting, drying, preserving with salt and other primitive forms of food processing, this ultimately led to the modern food processing methods of today, which give us an abundant, safe, convenient, affordable and nutritious food supply [1].

Processing foods have, on the one hand, a strong influence on the quality of food, both on the nutritional quality as well as on food safety. On the other hand, one can use different processing methods to improve the quality of food, e.g. fermentation processes. Nevertheless, most processing methods dilute the natural properties and the nutritional quality of food [1]. Obviously, the food processed should be of high nutritional and high natural quality. Some private standards or private companies demand that food processed should fulfill criteria of wholesome nutrition, where processing methods must be seen as relevant tools [2]

In the food processed sector EU Regulation 2092/91 does not require any further labeling in relation to the processing methods. Nearly the same situation applies to private standards for processing of organic food. There are some exceptions for some standards (like Demeter, Bio land, Nature land in Germany and Bio Suisse in Switzerland), where at least some of the processing methods have to be listed (e.g. in the Bio Suisse processing standards: homogenization, pasteurization, termination, sterilization, blanching, deep freezing, use of enzymes, etc.). Only some companies give additional information about their processing methods on the labels or in product-relate (d information material) [2].

A critical review of twelve Studies that investigated the level of consumer awareness and knowledge about foods processed had been done. A critical review of these studies suggests that, overall; 
there is some consumer awareness about organic foods around the world. This awareness is high especially in Western Europe, where the organic market is relatively well developed, compared to other regions of the world. Consumer awareness of food products in North America compares reasonably well with that of Western Europe [3].

When talking about animals, organically raised animals are those raised with organic feed and kept free from growth hormones and antibiotics, as well as oftentimes treated more humanely and given better areas to roam than their non-organic counterparts [4]. As the popularity of consuming organic foods has grown, several studies have compared the nutritional quality of food conventionally grown versus organically grown. More recent studies stated below have found that nutritionally speaking, conventionally grown foods and organically grown foods have no significant overall differences in their nutritional quality [4].

On preference of organic food and processed food, various studies have been done. Senauer B [5] found that the higher the knowledge of organic food and the more concerned consumers are about the environment and their health, the higher the probability that these consumer's will buy organic foods [5]. Therefore, this review aimed to assess the knowledge to words food processing and use of technology.

\section{Literature Review}

\section{Knowledge towards processed foods}

According to a study done in Bangkok on a sample of 150 processed food consumers, the majority of the respondents have a general knowledge of processed food but they have a lower knowledge about the hazards of processed food. Over $75 \%$ of the respondents have basic information of processed food such as what processed food is and the purpose and benefits of food processing. $80.5 \%$ of the respondents know the negative aspects of food processing. In contrast, a lower number of the respondents know the hazards of processed food [6].

\section{Foods processed}

Food manufacturers process foods and raw ingredients to add value to their products, in the form of longer shelf lives, added dietary nutrients, appealing textures and other features. Historically, the most important reason to process or prepare foods has been to make them last longer before spoiling. Early civilizations used techniques like salting meats, fermenting dairy (into cheese or yogurt, for example) and pickling vegetables. More recently, in the 1790s, Napoleon Bonaparte offered a prize to the scientist who could best develop ways to preserve foods for the armies of France; the competition prompted the discovery of safe canning practices by Nicolas Apart [7].

Louis Pasteur, working with beer and wine, would later discover pasteurization, a process that uses controlled amounts of heat to extend the shelf life of milk, juice and other products. Some argue that preservation is still the most important reason to process food because illness, even death, can result from eating spoiled food [7].

Processing and preparing foods can make them safer to eat by destroying toxins and eliminating or inhibiting pathogens. Techniques such as refrigerating, freezing, fermenting, drying and adding salt or sugar can slow or stop the growth of pathogens. Heat processes, such as pasteurization and cooking, can eliminate pathogens. Because these techniques help protect consumers, most cases of food borne illness involve raw animal products, fruits and vegetables that have been contaminated by pathogens [8].

\section{Processed food or history of organic foods}

Some forms of preservation can also maintain nutrient levels in certain foods. After fruits and vegetables are harvested, they begin to lose their nutritional quality. Freezing or canning can preserve levels of certain nutrients. Despite a common belief, canned foods are not necessarily less nutritious than their fresh or frozen counterparts Factors such as when the produce was harvested, how long it had been stored and how it will be prepared determine whether the fresh, frozen or canned version of a food is the most nutritious choice. Some of the studies which have been conducted with the objective of assessing the knowledge and preference of the communities towards processed foods are discussed [8].

Organic farming started in 1940 with J. I. Rodale that he formed his ideas based on previous work done in England, Germany, and the University of Missouri. The purpose of organic farming was to maintain soil fertility without the use of chemical fertilizers and pesticides. In 1980, the USDA Berglund Report was published providing recommendations on organic farming. However, it wasn't until 1990, with the Organic Foods Production Act (OFPA) that organic farming changed significantly. The Organic Farming Production Act provided regulations for certification. The first draft of this proposal was published in 1997 [9].

\section{Knowledge towards food processing}

A critical review of twelve Studies that investigated the level of consumer awareness and knowledge about foods processed had been done. A critical review of these studies suggests that, overall; there is some consumer awareness about foods around the world. This awareness is high especially in Western Europe, where the market is relatively well developed, compared to other regions of the world. Consumer awareness of food products in North America compares reasonably well with that of Western Europe [3].

Although there is general consumer awareness around the world, the literature also suggests that consumers have inconsistent interpretations about what is 'organic'. For example, in a survey of consumers in three California counties found that respondents associated food produce with no pesticides, no artificial fertilizer, no growth regulators, and residue-free products. Held man DR 
[3] studied the acceptance, knowledge and attitudes of university students towards organic and genetically modified foods. According to this study, women are more knowledgeable regarding organic foods than men as Truswell AS [10] found that the majority of students agreed that organic food is healthier and disagreed that organic foods are dangerous for their health. Additionally, the students agreed that organic food is safe for the environment and that there is little risk associated with consumption of organic food [10].

Respondents were asked, without any prompting, to outline their understanding of the concept of 'organic products' in terms of what it means or represents. The vast majority were able to give some explanation of food, with only a small number ( $5 \%$ Wales; $4 \%$ England/Scotland) saying they did not know or were unsure of what the concept meant [11].

Three quarters of comments (75\% Wales, 73\% England/ Scotland) included some explanation of the chemical free way in which organic food is produced. Around a third of these comments were rather generic, stating that the food was produced without chemicals, while a similar proportion mentioned a specific type of chemical not being used, such as pesticides, insecticides, herbicides and fungicides for crops, and antibiotics for livestock. Another 15\% of respondents thought that organic crops were grown without the use of artificial fertilizers [11].

Around one in five (21\% Wales; $20 \%$ England/Scotland) respondents stated that organic food was produced naturally, with small number of these specifying that growth enhancers are not used for growing or breeding. 44\% of respondents in Wales \& 47\% in England / Scotland mentioned 'grown without the use of chemicals' whereas only $10 \%$ and $3 \%$ respectively mentioned 'better for your health' [12].

\section{Preference towards organic foods}

Various studies have been done to determine preference of organic foods. Found that consumers that are more willing to buy organic, will tend to buy a larger quantity of organic products. In addition, they also found that the higher the knowledge of organic food and the more concerned consumers are about the environment and their health, the higher the probability that these consumer's will buy organic foods [4].

Consumers that are concerned about their health, the environment and the origin of products tend to buy organic products around $80 \%$ of the subjects surveyed by indicated that it is of great importance that there are no residues in the product. In contrast, between one third and less than half find it of great importance that products look appetizing, that animal welfare has been taken into consideration, that it is produced within the country, and that the production is environmentally friendly.
The main stated barriers for not purchasing organic foods was not willing to pay a price premium for organic products, lack of trust in any health effect from eating organic, and lack of trust in organic certification and control [4].

Studied the acceptance, knowledge and attitudes of university students towards organic and genetically modified foods According to this study, the cost of organic foods influenced purchase intent of the students Furthermore, students with higher incomes are more likely to purchase organic products [4].

A survey was applied to a random sample of 109 students (69 female, 40 male) at two different colleges in Atlanta, Georgia by Juliana B. Galva with the objective of "Consumer Perception, Knowledge and Purchase Motivators for Organic and Genetically Modified Foods" Sixteen (27\%) of 59 participants did not consume organic foods and did not grow up with a homegrown vegetable garden. Of the 44 participants consuming organic food, 36 (82\%) grew up with homegrown produce. Six of the seven participants did not purchase organic foods but consumed home cooked meals growing up. Of the 95 participants who consumed organic products, 72 ate home cooked meals during childhood [13].

According to the above study fifty-one (77\%) of the 66 participants did not consume organic food but were influenced by the media when making food choices. Twenty-seven of the 36 participants indicated that they consumer organic foods and are influenced by the media when making decisions regarding their food choices. Forty (68\%) of 59 participants responded that they do not consume organic food; however, that they are influenced by local sustainability movements. Thirty-eight (88\%) of the 43 participants reportedly consumed organic foods and were influenced by local movements; however, five individuals who consumed organic foods reported no influence by local movements. Twenty-seven participants reported no consumption of organic foods and that family influences their food choices. Of the 68 participants consuming organic food, 52 (76\%) also reported that family has an impact on what foods are chosen [13].

\section{Preference towards processed foods}

The study of the Bangkok stated that out of the 150 participants $28 \%$ of the respondents consume processed food on a regular basis. The top 3 kinds of processed food that consumers like to consume are milk products, beverages, and snacks or cereals. The major reasons for consuming processed food are convenience and availability followed by variety and taste. Quality, safety, and nutrition are not major reasons for consuming processed food [14].

The finding is different from Lotto and Hello (1996) since they indicated that consumers have positive opinions about the taste and convenience of food, processed and unprocessed food. The factors that most affect consumer decisions to purchase processed 
food are variety followed by advertising, price or promotion, taste, and quality or safety [14].

The result also showed that $35.5 \%$ of the respondents are satisfied with processed food in general while $59.3 \%$ of the respondents are uncertain. The majority of the respondents perceive that they have a medium level of interest involving conscious awareness or thinking about food and most of them find information about food from packaging or labeling and from background knowledge. The rest of the respondents find that knowledge from advertising and past experience [15].

\section{Processed-Food Export Trends and Developing Countries}

The food-processing sector has recently received attention within the framework of discussions on export-led industrialization in developing countries. Athukorala and Sen (1998) have elaborated a general analysis of this dynamic arising from their earlier reflections on the performance of Chilean Agri food and fishing exports. The share of manufacturing exports in total world trade has increased from $66 \%$ to $81 \%$ from $1970-1994$ and developing country share in manufacturing exports has leapt from $6 \%$ to $24 \%$. At the same time, processed food as a proportion of world nonmanufacturing exports increased from $26 \%$ to $37 \%$. This trend was global but developing countries' share of processed food in non-manufacturing exports increased from $23 \%$ to $38 \%$, while the corresponding figures for developed countries was $28 \%$ to $36 \%$. With notable exceptions (Bangladesh), middle and high-income developing countries have performed better than low- income countries.

The authors note that non-food manufacturing exports from developing countries tend to have a faster growth record, although this is by no means universal.

More importantly, they observe that there is a strong correlation between manufacturing export growth and food-processing export growth, which leads them to conclude that, for manufactured products, the key determinant is the domestic policy framework rather than resource endowments, which should be seen rather as a necessary pre-condition, although it remains the critical factor in the case of primary product exports.

Five developing countries - Argentina, Brazil, Malaysia, Thailand and Taiwan were responsible for $40 \%$ of total processed food exports by developing countries, but the evidence points to a continuous increase in the number of developing countries participating in such exports. Countries with a superior overall export record - Chile, Thailand, Indonesia, Malaysia, Turkey, Tunisia, Guatemala, El Salvador and Sri Lanka - have also been most notable in the increase of processed food in their share of total non-manufactured exports. It should be noted, however, that particularly in the case of middle and high-income developing countries, the growth rate of manufacturing exports has far exceeded that of processed foods. Nevertheless, for more than half of the 37 developing countries selected exports in 1994.

The authors also note, what they see as a remarkable shift in the commodity composition of processed food exports since the '70s with current export growth coming from products which were of less importance in the initial period. Processed fish, whose share in total processed food exports from developing countries in 1970 was $8.8 \%$, occupied $30.7 \%$ of total exports in 1994 . Less spectacularly preserved fruit has also continued to increase its share over time. For most developing countries these two products accounts for some $40 \%$ of total processed food exports. For as many as 17 countries, processed fish alone has accounted for $40 \%$ of total exports. On the other hand, traditional products -meat, sugar, animal feeds, and vegetable oils - have either fluctuated wildly or declined in importance.

Having established the strategic role of processed food exports, the authors then consider their implications for employment, terms of trade, knowledge and technology spillovers.

They note that there is no clear relation between income levels and export growth and that, furthermore, the final stages of foodprocessing tend to be laboring intensive, particularly canning and fish-processing. The authors, also provisionally, conclude that trade implications are positive when compared to primary products based on income and price elasticity of demand trends and in this sense processed foods are similar to traditional manufactured products as a whole. Their spill-over effects, however, would seem to be superior to traditional manufacturing since they are less dependent on imports, involve a greater degree of learning through interaction with exporters, and have to respond to more demanding quality specifications.

A similarly optimistic assessment can be found in the UNCTAD report: "Opportunities for Vertical Diversification in the Food Processing Sector in Developing Countries" (1997) which analyses the prospects for four groups of food products: horticulture, fish, meat and tropical beverages. Trade opportunities are identified in three major country blocs: higher income developing countries such as South- East Asia as a result of market expansion; the economies of Eastern Europe and the Russian Federation because of the transition effect; developed and advanced developing countries through the impact of changing life-styles. The principal problems of market access are identified.

\section{The Food Processing Sector and the Domestic Markets of Developing Countries}

Since the UNCTAD study: Some Recent Trends in the Transfer and Development of Technology (1980) the macro economic and regulatory climate has suffered a sea-change. Import substitution has given way everywhere to export oriented growth strategies and most developing countries have now adjusted to the post-Uruguay 
Round WTO framework. An increased participation of developing countries in the share of global manufactured exports is seen to vindicate and point the way for future development (Global Forum of Industry, 1995). The dominant orthodox view focuses primarily on the need for macro-economic and regulatory adjustment, which is seen to be the basic strategy for integrating developing countries into global economic growth under the coordination of transnational's in the form of FDI or external sub-contracting According to this scenario, sectarian measures would be focused on policies to promote SMEs, combined with initiatives directed at poverty alleviation.

Other analysts have pointed to the selective character of FDI, particularly in the case of the least developed countries where deindustrialization (Africa) or a de-intensification of industrialization (Latin America) have been identified in this period and have stressed the need for more pro-active industrial strategies at domestic level. The case of South Korea and other Asian countries, on the one hand, where FDI was less important, and the inspiration of the "Third Italy" for the development of cluster strategies, would provide the principal support for this approach.

\section{The food processed of technology}

Some Recent Trends in the Transfer and Development of Technology (1980) the macro economic and regulatory climate has suffered a sea-change. Import substitution has given way everywhere to export oriented growth strategies and most developing countries have now adjusted to the post-Uruguay Round WTO framework. An increased participation of developing countries in the share of global manufactured exports is seen to vindicate and point the way for future development (Global Forum of Industry, 1995).

The dominant orthodox view focuses primarily on the need for macro-economic and regulatory adjustment, which is seen to be the basic strategy for integrating developing countries into global economic growth under the coordination of transnational's in the form of FDI or external sub-contracting. According to this scenario, sectarian measures would be focused on policies to promote SMEs, combined with initiatives directed at poverty alleviation.

Other analysts have pointed to the selective character of FDI, particularly in the case of the least developed countries where deindustrialization (Africa) or a de- intensification of industrialization (Latin America) have been identified in this period and have stressed the Need for more pro-active industrial strategies at domestic level. The case of South Korea and other Asian countries, on the one hand, where FDI was less important, and the inspiration of the "Third Italy" for the development of cluster strategies, would provide the Principal support for this approach.

A further fundamental change has been the shift to the formation of regional blocs which has accompanied globalization, and which has now also become a feature of the developing world. In Latin
America, Mexico became integrated into NAFTA, while the southern Cone developed the merciful, complementing earlier blocs, such as the Andean pact, with similar initiatives in Central America and the Caribbean. In Asia, Japan had long deemed the focus of regional integration, but more recently the ASEAN countries have established a free trade area with China, principally as a strategy for benefiting from FDI Flows.

After many setbacks in Africa, a new regional dynamic is emerging in the SADC, with South Africa as its hub. These tendencies to regionalization are now rein for

\section{Conclusion}

In general majority of the community respondents thought that food processing is healthy and contain high nutritional value product practices are in harmony with nature, environment and animals are getting respect from organic farmers who do not use chemicals and GMOs in farming. This paper reviews the consumer attitude by looking at motivations and barriers towards organic consumption. Health is the common first motivation and supporting product movement and sustainability has got the same ratings in each survey.

\section{References}

1. Anderson J, Wachenheim C, Lesch W (2006) Perceptions of genetically modified and foods processing and use of technology. Volume 9.

2. Ayaz A, Bilici S, Uyar M, Ay B, Borekci S, Kook E (2011).

3. Held Man DR, Hartel RW (1997) Principles of Food Processing. Chapman \& Hall New York.

4. Thilmany D (2006) The US food industry: Important trends and emerging issues for the USDA. Agribusiness Marketing Report. Colorado State University, USA.

5. Senauer B, Asp E, Kinsey J (1991) Food Trends and the Changing Consumer. St. Paul (Eb) Eagan Press Minnesota.

6. Monteiro CA, Levy RB, Claro RM, Castro IRR De, Cannon G (2011) Increasing consumption of ultra-processed foods and likely impact on human health. Public health nutrition Brazil 14(1): 5-13.

7. Alzamora SM, Tapia MS, López Malo A (2000) Minimally Processed Fruits and Vegetables Fundamental Aspects and Applications. Aspen Publishers Gaithersburg.

8. Slimani N, Deharveng G, Southgate Da T (2009) Contribution of highly industrially processed foods to the nutrient intakes and patterns of middle study. European Journal of Clinical Nutrition 63 Suppl 4: S206-S225.

9. Wiggins G, McTighe J (1998) Understanding by Design. Association for Supervision and Curriculum Development Alexandria.

10. Truswell AS, Brand JC (1985) Processing food. British Medical Journal 291(6503): 1186-1190.

11. Monteiro CA, Levy RB (2010) A new classification of foods based on the extent and purpose of their processing. Public Health Nutrition 26(11): 2039-2049.

12. Monteiro CA (2009) Nutrition and health The issue is not food nor nutrients so much as processing. Public health nutrition 12(5): 729-731.

13. Kim B (2011) Google search results for processed food.

14. Smith JS, Hui YH (2004) Food Processing Principles and Applications. Wiley-Blackwell, Lowa, USA. 
15. Halweil B (2002) Home Grown: The Case for Local Food in a Global Market. World watch Institute Danvers.

16. Dimitri C, Greene C (2002) Recent growth patterns in U.S processed food market.

17. Ensminger A, ME Ensminger, JE Konlande, JRK Robson (1994) Foods \& Nutrition. Encyclopedia CRC Press, Volume 1 ( $2^{\text {nd }}$ edn), Boca Raton, USA pp. 1208

18. Fellows P (2000) Food Processing Technology: Principles and Practice Second. CRC Press Boca Raton, USA.

19. Garcia A, \& Magistris T (2007) Food product purchase behavior: A pilot study for urban consumers Italy. 5(4).

20. Horst K Vander, Brunner Ta, Siegrist M (2011) Ready-meal consumption: associations with weight status and cooking skills. Public Health Nutrition 14(2): 239-245.

21. Maroulis ZB, Saravacos GD (2003) Food Process Design. NY Marcel Dekker (Ed), New York.
22. Nestle M (2002) Food Politics: How the Industry Influences Nutrition and Health. Berkeley University of California Press, Volume 3.

23. 0 Keefe JH, Cordain L (2004) Cardiovascular disease resulting from a diet and lifestyle at odds with our paleolithic genome: how to become a 21st-century hunter-gatherer. Mayo Clinic Proceedings. 79(1): 101-108.

24. Ohlsson T, Bengtsson N (2002) Minimal Processing Technologies in the Food Industry. CRC Press, Boca Raton, FL, USA.

25. Shi J, Maguer ML (1998) Functional Foods: Biochemical \& Processing Aspects. Volume 2. Technomic Publishing Company, Lancaster, PA, USA.

26. Sustainable Agriculture Research and Education (SARE) (2012) History of organic farming in the United States.

27. Wiley RC (1994) Minimally Processed Refrigerated Fruits \& Vegetables. Chapman \& Hall, New York, USA. 